\title{
ASPECTS OF ATHENIAN DEMOCRACY
}

\author{
BY \\ ROBERT J. BONNER \\ PROFESSOR OF GREEK IN THE \\ UNIVERSITY OF CHICAGO
}

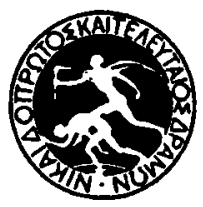

UNIVERSITY OF CALIFORNIA PRESS

BERKELEY, CALIFORNIA

I 933 
Copyright, 1933

BY

The Regents of the University of California

\author{
University of California Press \\ Berkeley, California
}

Cambridge University Press

London, England

PRINTED IN THE UNITED STATES OF AMERICA 
TO

\section{MAURICE HUTTON}

PRINCIPAL EMERITUS OF UNIVERSITY COLLEGE

FOR FIFTY YEARS

CLOSELY IDENTIFIED WITH THE DEVELOPMENT

OF THE HONOURS COURSE IN CLASSICS IN

THE UNIVERSITY OF TORONTO 
